\title{
ヒト培養血管内皮細胞の $\mathrm{PGI}_{2}$ 産生に及ぼす \\ Ca 拮抗薬の影響とその作用機序
}

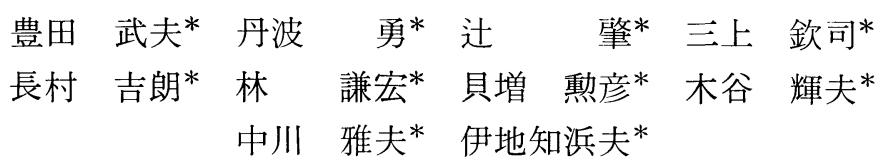

Effect of $\mathrm{Ca}$ antagonists on $\mathrm{PGI}_{2}$ generation in cultured human vascular endothelial cells with special reference to their mode of action

Takeo TOYODA*, Isamu NIWA*, Hajime TSUII*, Kinji MIKAMI*, Kichiro OSAMURA*, Kenhiro RIN*, Isao KAIMASU*, Teruo KITANI*, Masao NAKAGAWA* and Hamao IJICHI*

Key words: endothelial cell, $\mathrm{PGI}_{2}$, Ca antagonist, c-AMP, calcium ion

Endothelial cells were isolated from human umbilical cord and cultured by the modified method of Jaffe et al. 6-keto $\mathrm{PGF}_{1 \alpha}$ content in supernatant over the monolayer cells was employed as the parameter of $\mathrm{PGI}_{2}$ generation. $\mathrm{PGI}_{2}$ generation was increased by addition of Nifedipine $(\times 2.10)>$ Diltiazem $(\times 1.78)>$ Verapamil $(X 1.59)$. This effect was diminished when the cells were pretreated with each of Mepacrine or ASA, even when Arachidonic acid or $\mathrm{PGH}_{2}$ was added. The increase of $\mathrm{PGI}_{2}$ generation by $\mathrm{Ca}$ antagonist was considered to be due to activation of phospholipase $\mathrm{A}_{2}$. The $\mathrm{PGI}_{2}$ generation induced by $\mathrm{A}-23187$, Arachidonic acid, or $\mathrm{PGH}_{2}$ was remarkably decreased by preincubating the cells with TMB-8. The dependency of $\mathrm{PGI}_{2}$ generation upon the intracellular $\mathrm{Ca}^{++}$ was considered to be dominant in the early step of AA cascade. The enhanced $\mathrm{PGI}_{2}$ generation by A-23187 or Diltiazem was almost diminished in $\mathrm{Ca}^{++}$free medium. While preincubation with MIX caused increase in intracellular c-AMP concentration, and decrease in $\mathrm{PGI}_{2}$ generation, addition of Diltiazem had no 
effect on c-AMP concentration. Through these experimental results, it is concluded that the enhanced $\mathrm{PGI}_{2}$ generation via phospholipase $\mathrm{A}_{2}$ induced by Diltiazem may be originated from intra- and extra- cellular $\mathrm{Ca}^{++}$mobilization and may not be dependent on $\mathrm{c}-\mathrm{AMP}$ process.

\section{はじめに}

われわれは従来大動脈輪ならびに培養血管内 皮細胞を用いて，これらの $\mathrm{PGI}_{2}$ 産生に拈よぼ す種々の薬剤の効果につき報告してきたが1), 今回はヒト培養血管内皮細胞を用いてこの $\mathrm{PGI}_{2}$ 産生に扣よぼす $\mathrm{Ca}$ 拮抗薬の影響, なら びそその作用機序を検討した。

\section{I. 方 法}

Jaffe ら²)の方法に準じて，ヒト臍帯静脈よ り血管内皮細胞を分離培養し, 培養開始 $5 \sim 7$ 日後の Confluent 形成した培養細胞を用いた。 まず保生液に種々の濃度の Nifedipine (NDP), Diltiazem (DTZ) または Verapamil (VPM) を添加し, 内皮細胞より産生される 6-Keto P $\mathrm{GF}_{1 \alpha}$ をIA 法にて定量した ${ }^{3)}$. 次にこれら 諸薬剤の $\mathrm{PGI}_{2}$ 産生に括よぼす作用機序を検討 するため, (1)Mepacrine 前処置後アラキドン酸 (A.A.)を添加した系，ならびにアセチルサリ チル酸 (ASA) 前処置後 $\mathrm{PGH}_{2}$ を添加した系 に，DTZ またはVPMをそれぞれ添加した実 験系, (2)TMB-8 にて前処置後 Ca ionophore A-23187，A.A. または $\mathrm{PGH}_{2}$ をそれぞれ別個 に添加した実験系，(3)EGTA の添加により $\mathrm{Ca}^{++}$free とした保生液に A-23187 または D
$\mathrm{TZ}$ をそれぞれ添加した実験系，(4)MIX 前処 置後 DTZ を添加した実験系，などについて保 生液中の $\mathrm{PGI}_{2}$ 産生量, 拈よび内皮細胞内 cAMP 量を測定した4).

\section{II. 結 果}

(1)培養内皮細胞の保生液への諸薬剤の添加は $\mathrm{PGI}_{2}$ 産生を増加させ，その効果は $\mathrm{NDP}(2.1$ 倍) >DTZ (1.78倍) >VPM (1.59倍) の順に 大であった. (2)Mepacrine による phosholipase 阻害下での A.A. の添加系, ならびに ASA による cyclooxygenase 阻害下での $\mathrm{PGH}_{2}$ の添 加系では DTZ 抢よび VPM による $\mathrm{PGI}_{2}$ 産 生増加作用は認めなかった。(3)A-23187, A.A., または $\mathrm{PGH}_{2}$ の添加時には $\mathrm{PGI}_{2}$ 産生は増加 するが，この増加は TMB-8 前処置により著 明に抑制され，この抑制効果は A-23187 添加 時が最も著明であった（表 1).(4)EGTA 添加 による $\mathrm{Ca}^{++}$free の保生系への A-23187 また は $\mathrm{DTZ}$ の添加時には $\mathrm{PGI}_{2}$ 産生増大作用は著 減した（表 2 ). (5)MIX 前処置により内皮細胞 内 $\mathrm{c}-\mathrm{AMP}$ 量は増大し, $\mathrm{PGI}_{2}$ 産生量は低下乙 た（図 1)。むた $1 \mathrm{mM}, \mathrm{MIX}$ 前処置下での D $\mathrm{TZ}\left(10^{-6} \mathrm{M}\right)$ の添加時には c-AMP 量, およ び $\mathrm{PGI}_{2}$ 産生量には有意の影響はなかった（図 2 ).

Table 1 Effect of TMB-8 on $\mathrm{PGI}_{2}$ generation in cultured vascular endothelial cells. (6-keto $\mathrm{PGF}_{1}\left(\mathrm{ng} / \mathrm{m} l / 2 \times 10^{5}\right.$ cells) \& $\%$ change)

\begin{tabular}{|c|c|c|}
\hline & control & $\begin{array}{l}\text { pretreated with } \\
\text { TMB-8 ( } 1 \mathrm{mM}, 5 \mathrm{~min})\end{array}$ \\
\hline Buffer A $\left(\mathrm{CaCl}_{2} 1.8 \mathrm{mM}\right)$ & $21.91+3.08$ & $\begin{array}{l}0.13 \pm 0.08 \\
\quad(0.47 \pm 0.22)\end{array}$ \\
\hline add $\mathrm{Ca}$ ionophore A $23187\left(10 \mu \mathrm{N}_{\mathrm{i}}\right)$ & $187.91 \pm 15.68$ & $0.06 \pm 0.01$ \\
\hline $\begin{array}{l}\text { add Arachidonic acid }(20 \mu \mathrm{M}) \text { pretreated with } \\
\text { Mepacrine }\left(10^{-4} \mathrm{M}, 15 \mathrm{~min}\right)\end{array}$ & $263.49+38.78$ & $\begin{array}{l}19.64 \pm 2.48 \\
(8.19 \pm 1.17)\end{array}$ \\
\hline $\begin{array}{l}\text { add } \mathrm{PGH}_{2}(5.68 \mu \mathrm{M}) \text { pretreated with } \mathrm{ASA} \\
(1 \mathrm{mM}, 30 \mathrm{~min})\end{array}$ & $202.47 \pm 46.90$ & 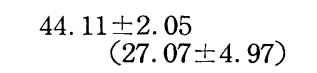 \\
\hline
\end{tabular}


Table 2 Effect of extracellular $\mathrm{Ca}^{++}$concentration on $\mathrm{PGI}_{2}$ generation in cultured vascular endothelial cells (\% change)

\begin{tabular}{c|c|c|c}
\hline $\begin{array}{l}\text { Culture } \\
\text { medium }\end{array}$ & untreated & $\begin{array}{l}\text { Ca ionopho- } \\
\text { re A 23187 } \\
(10 \mu \mathrm{M})\end{array}$ & $\begin{array}{c}\text { Diltiazem } \\
\left(10^{-6} \mathrm{M}\right)\end{array}$ \\
\hline $\mathrm{Ca}^{++}(+)$ & $100 \pm 0$ & $932 \pm 97$ & $178 \pm 23$ \\
$\mathrm{Ca}^{++}(-)$ & $105 \pm 8$ & $157 \pm 12$ & $121 \pm 12$
\end{tabular}

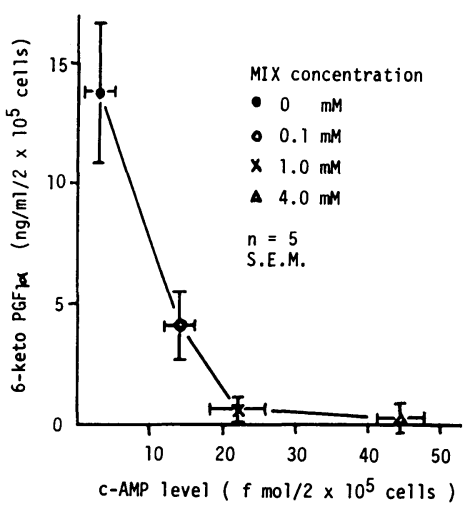

Fig. 1 Relationship between cAMP level and 6-keto $\mathrm{PGF}_{1}$ generation in cultured vascular endothelial cells.

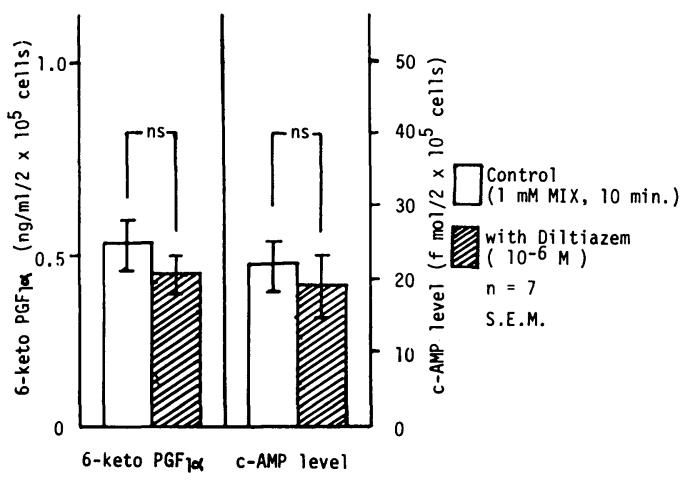

Fig. 2 Effect of Diltiazem on $\mathrm{PGI}_{2}$ generation and c-AMP level in cultured vascular endothelial cells

\section{III. 考案}

従来より血管内皮細胞での $\mathrm{PGI}_{2}$ 産生は諸因 子により変動することが報告されており5)6778) われわれは前回，本学会に拈いてヒト培養血管 内皮細胞の $\mathrm{PGI}_{2}$ 産生がニトログリセリンによ
り増加することを報告した。今回は NDP，DT $Z, V P M$ 等の $\mathrm{Ca}$ 拮抗薬が ヒト培養血管内皮 細胞に扣いて $\mathrm{PGI}_{2}$ 産生を増加せしめることを 確認し，この作用点は phospholipase $\mathrm{A}_{2}$ また はこれ以前の段階と推定された. AA cascade に扮ける $\mathrm{PGI}_{2}$ 産生は細胞内 $\mathrm{Ca}^{++}$の動員に依 存し，その依存度は AA cascade の上位の段 階ほど強度であった。また，これらの薬剤の $\mathrm{PGI}_{2}$ 産生増大作用の発現は主に細胞外 $\mathrm{Ca}^{++}$ の移動に起因し，Adenylate cyclase の不活性 化，ならびに，c-AMP の低下による $\mathrm{Ca}^{++}$ storage site よりの $\mathrm{Ca}^{++}$遊離の促進 ${ }^{9)}$ に起因 する過程は否定的であると推定された.

\section{文献}

1) Takeo Toyoda, Ryo Okano, Kiniji Mikami, Shunyo Kanayama, Hajime Tsuji, Kichiro Osamura, Kenhiro Rin, Isao Kaimasu, Masao Nakagawa, and Hamao Ijichi, : Effect of vasodilators on prostacyclin synthesis of cultured human umbilical endothelial cells. Blood \& Vessel, 14; 488 490, 1983.

2) Eric A. Jaffe, Ralph L. Nachman, Carl G. Becker, and Richard C. Minick: Culture of human endothelial cells derived from umbilical veins. J. Clin. Invest., 52; 2745 2756, 1973.

3) Instruction Manual For The Measurement of 6-keto-Prostaglandin $F_{1}$ Levels in Tissue and Biological Fluids, Catalog No. NEK008, New England Nuclear, 1-14, June 1982.

4) YAMASA Cyclic AMP Assay Kit, Cyclic GMP Assay kit Technical Guide.

5) Babette B. Weksler, Christopher W. Ley, and Eric A. Jaffe: Stimulation of endothelial cell prostacyclin production by thrombin, trypsin, and the ionophore A 23187. J. Clin. Invest., 62; 923 930, 1978.

6) Jay M. Sullivan, Darrell R. Patrick, B. S.: Release of prostaglandin $\mathrm{I}_{2}$-like activity from the rat aorta. Effect of captoril, furocemide, and sodium. Prostaglandins, 22; 575 585, 1981.

7) Vittorio Tomasi, Cristina Meringolo, Gio- 
Vanna Bartolini and Marina Orlandi: Biosynthesis of Prostacyclin in rat liver endothelial cells and its control by prostaglandin E2. Nature, 273; 670 671, 1978.

8) Richard L. Levin, Eric A. Jaffe, Babette B. Weksler and Karen Tack-Goldman: Nitroglycerin stimulates synthesis of prostacyc- lin by cultured human endothelial cells. J. Clin. Invest., 67; 762 769, 1981.

9) Abigail F. Adams, Brotherton and John C. Hoak: Role of $\mathrm{Ca}^{2+}$ and cyclic AMP in the regulation of the production of prostacyclin by the vascular endothelium. Proc. Natl. Acad. Sci. U.S.A., 79; 495 499, 1982.

\section{のわが国唯一のビタミンB $\mathrm{B}_{12}$ 研究の完全な集大成！}

\section{ビタミン B 12 一基礎と臨床}

\section{編集 京都大学内科教授 内野治人 専門医24氏分担執筆} A 5 判 367頁 図157 表73 定価7,800円(干200円)

ビタミン B $_{12}$ は最も新しく発見されたものであるが，その構造の特異性:や作用の独白性 から、その研究の進少は著しいものがある。最近では，その闰族体の臨休忍用が公くなっ てきたものの，生化学，酵素学:などの基盤にたった合理的な使用法はまだほど䢱い所にあ

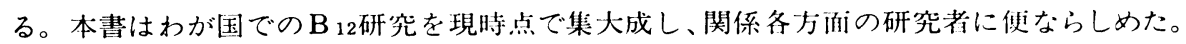

○内容：第 1 章 ビタミン $\mathrm{B}_{12}$ 研究の進少と問题点，第 2 章 ビタミン $\mathrm{B}_{12}$ の吸仪, 第 3 草 ビタミン $\mathrm{B}_{12}$ の晹管吸

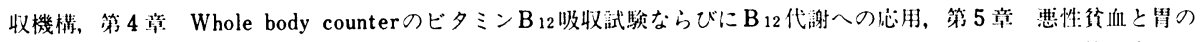

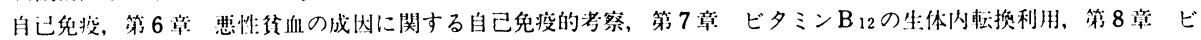
夕ミン $\mathrm{B}_{12}$ 結合焦日，第 9 章 Acid-resistant binding capacity と "granulocyte related" binding protein:こついて,

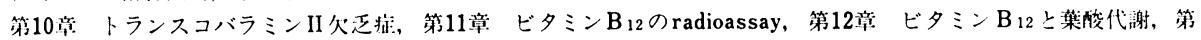

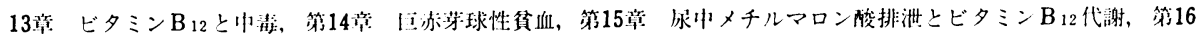

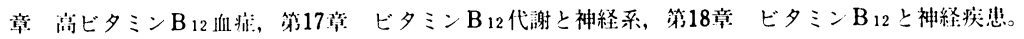

